УДК 657.6:339.9

\title{
Аліна Семенець,
}

доктор економічних наук, доцент,

професор кафедри міжнародного бізнесу, фінансів та обліку,

Харківський торговельно-економічний інститут,

Київський національний торговельно-економічний університет,

ORCID ID 0000-0003-2948-6238

a.semenets@knute.edu.ua

DOI 10.29038/2524-2679-2021-01-386-397

\section{ВНУТРІШНІЙ КОНТРОЛЬ ТА СИСТЕМА ВНУТРІШНЬОГО КОНТРОЛЮ В КОНТЕКСТІ МІЖНАРОДНОГО БІЗНЕСУ: ФОРМАЛІЗАЦІЯ ДЕФІНІЦІЙ}

Нині незаперечно й істотно зростають роль $і$ значення внутрішнього контролю у фінансово-господарській діяльності й управлінні підприємствами та економікою загалом. Метою иієї роботи є дослідження означених питань для систематизації та узагальнення наявних $і$ можливих підходів для визначення понять «внутрішній контроль» $i$ «система внутрішнього контролю». Проведені дослідження виявили неоднозначність поглядів теоретиків і практиків у сфері контролю на наріжні та атрибутивні питання контролю, а саме: щуодо сутності, змісту, ролі, значення внутрішнього контролю та системи внутрішнього контролю в управлінні підприємством, його фінансово-господарською діяльністю. Це вкрай негативно позначається на практичі ведення контрольної діяльності, а відтак негативно впливає на всю систему управління підприємством $і$, як наслідок - на кінцеві результати фінансово-економічної діяльності. За результатами досліджень виявлено, щзо формалізація дефініцій «внутрішній контроль», «система внутрішнього контролю» має величезне значення для розвитку понятійно-категоріального апарату як у теорії контролю й управління, так $і$ економічної науки загалом, а також чинить визначальний вплив на практику управління, контролю та ведення фінансово-господарської діяльності в сучасних умовах господарювання. Узагальнено й згруповано реальні підходи вітчизняних $i$ зарубіжних фахівців у сфері контрольної та управлінської діяльності як теоретиків, так і практиків до визначення понять «внутрішній контроль», «система внутрішнього контролю». Проведені дослідження переконливо свідчать, що впровадження систем внутрішнього контролю значної частини вітчизняних підприємств, особливо великих і середніх, що перебувають у кризовому й передкризовому стані, на сьогодні є однією з першочергових

(C) Семенеи̧ь А., 2021 
завдань, щуо сприяє подоланню кризових явищ, істотному зниженню ризиків $i$, як наслідок, підвищенню ефективності всієї фінансово-господарськой діяльності. Результати дослідження можуть бути використані в практиці міжнародного бізнесу, в економічній сфері міжнародних відносин. За результатами проведених досліджень надано авторське визначення понять «внутрішній контроль» та «система внутрішнього контролю», щуо, на нашу думку, має сприяти подальшому розвитку теорї̈ й практики контрольної діяльності, менеджменту, міжнародного менеджменту.

Ключові слова: внутрішній контроль; система внутрішнього контролю; управління; контроль; аудит; міжнародний менеджмент; міжнародний бізнес.

\section{1. ВСТУП}

Постановка проблеми. Значна кількість вітчизняних підприємств нині перебуває у важкому фінансово-економічному стані. В аналогічному стані перебувають підприємства, що працюють у сфері міжнародного бізнесу. Головними причинами цього можна назвати загальне економічне становище й економічну політику держави. Водночас одним 3 істотних недоліків, що гостро проявляється в економіці, $є$ низький рівень та якість управління, нездатність управлінського персоналу підприємства приймати грамотні раціональні рішення в сучасних швидко мінливих економічних умовах. Особливо гостро це проявляється в кризових ситуаціях, у ситуаціях із підвищеними ризиками. Одним із найважливіших й ефективних напрямів підвищення якості управління на всіх рівнях, є впровадження в практику систем внутрішнього контролю та аудиту. Особливо ефективним є застосування систем внутрішнього контролю й аудиту на великих і середніх підприємствах незалежно від форми власності, у відомствах, галузях та в цілому в економіці країни, у міжнародних відносинах, менеджменті на всіх рівнях, міжнародному менеджменті. Водночас внутрішній контроль у визначених формах та умовах досить ефективний і для підприємств середнього й малого бізнесу. Однак у процесі створення системи внутрішнього контролю на підприємствах виникає низка проблем: недостатня кваліфікація кадрів, що пов'язано з низькою теоретичною підготовкою та відсутністю практичного досвіду створення подібних систем; відсутність розвиненої й апробованої теоретичної бази, що пов'язано з недостатністю наукових досліджень і теоретичних розробок у цьому напрямі; відсутність законодавчої бази, котра чітко регламентує створення й оцінку систем внутрішнього контролю й аудиту на підприємстві; оцінка їі ефективності тощо. 
Для значної частини вітчизняних підприємств, підприємств міжнародного бізнесу, особливо великих і середніх, що перебувають у кризовому та передкризовому стані, не лише актуальним, але й необхідним $є$ створення систем внутрішнього контролю та аудиту, що переведе рівень управління підприємством на якісно інший вищий рівень. Цей захід сприятиме створенню дієвого й ефективного корпоративного управління, що, урешті-решт, позитивно позначиться на кінцевих фінансово-економічних результатах діяльності. Сучасному міжнародному бізнесу доводиться функціонувати в постійно мінливих умовах зовнішнього навколишнього середовища. Стрімко зростають ризики та невизначеності, які кардинально впливають на процеси, що проходять у міжнародних відносинах, міжнародному бізнесі. Для активізації й підвищення ефективності систем внутрішнього контролю та аудиту, а також оптимізації контрольноконсультаційної роботи на підприємствах потрібна адекватна оцінка їхньої діяльності.

Аналіз останніх досліджень і публікацій. Вивченням особливостей внутрішнього контролю, системи внутрішнього контролю займалися такі вчені, як М. Т. Білуха [1], Р. Бойко [2], Б. А. Боррас [3], Т. А. Бутинець [4], І. К. Івейор [5], Е. Е. Коба [6], В. Лакіс та Л. Гірюнас [7], М. В. Мельник, О. С. Пантелєєв та А. Л. Звездін [8], М. І. Павлов [9], Б. Н. Соколов і В. В. Рукін [10], О. Хенк [11] й ін. Проте підходи до визначення внутрішнього контролю та системи внутрішнього контролю, які пропонують науковці, $\epsilon$ різноспрямованими, а питання, що стосуються понять внутрішнього контролю, системи внутрішнього контролю $є$ недостатньо вирішеними, що призводить до слабкості й невизначеності теорії внутрішнього контролю, іï недостатності для ефективного розв'язання практичних питань, практичної побудови системи внутрішнього контролю. Це слугувало відправною точкою та передумовою для проведення таких досліджень.

Мета статті - систематизація та узагальнення наявних підходів до визначення понять «внутрішній контроль» і «система внутрішнього контролю», визначення сутності та змісту «внутрішнього контролю», «системи внутрішнього контролю».

Методика дослідження. Для досягнення визначеної мети дослідження використовували такі загальнонаукові методи дослідження, як аналіз, синтез, індукція, дедукція, моделювання, узагальнення, порівняння, хронологічний аналіз. Широко застосовували системний аналіз.

Методологічною й інформаційною основою дослідження $є$ матеріали періодичних видань, наукові праці, нормативно-правова база України, 
звіти й матеріали установ та організацій України, СС й інших професійних організацій бухгалтерів, аудиторів України та світу.

\section{2. РЕЗУЛЬТАТИ ДОСЛІДЖЕННЯ}

На сучасному етапі розвитку економіки України вирішальне значення має інформаційний складник для якості управління на всіх рівнях. Рівень та якість управління багато в чому визначаються достовірністю, релевантністю, якістю інформації, що використовується в управлінському процесі. Щодо цього впровадження систем внутрішнього контролю на підприємствах зараз є одним із першочергових завдань, що сприяє подоланню кризових явищ, істотному зниженню ризиків і, як наслідок підвищенню ефективності всієї фінансово-господарської діяльності. Якщо це перетвориться в тенденцію, то тоді можна говорити про подолання кризи економіки України.

Економічна категорія «контроль» тією чи іншою мірою завжди присутня там, де існує не лише фінансово-господарська діяльність, а й управлінська діяльність загалом. 3'явившись на початку XVIII ст., поняття контролю в процесі еволюції та значного розширення виконуваних функцій і сфери застосування призвело до появи на початку XX ст. поняття системи контролю, що містить певні нові елементи. Нові функції та сфери застосування контролю, нові тенденції в економічному розвитку стимулювали його концептуальний розвиток. Із перебігом часу контроль трансформувався від так званого «підтверджувального» до нині системной ризик-орієнтованого, зі зміцненням тісних взаємозв'язків з управлінським обліком, аналізом й іншими дисциплінами.

Незважаючи на глибокі різноспрямовані дослідження та практичний розвиток, низка напрямів внутрішнього контролю вимагає подальших теоретичних досліджень. До питання про визначення поняття «внутрішній контроль» ми вже зверталися раніше [12]. Тут же хотілося б продовжити цей напрям, тому що, на наше переконання, визначення поняття $є$ визначальним для всього комплексу питань, пов'язаних із цим поняттям, не $\epsilon$ винятком і «внутрішній контроль». Звертає на себе увагу те, що ряд авторів змішують поняття «внутрішній контроль» і «система внутрішнього контролю». Ми погоджуємося 3 [6; 9; 10] у тому, що ці поняття мають кожне своє смислове навантаження.

Дослідження особливостей функціонування внутрішнього контролю й формування системи внутрішнього контролю неможливе без чіткого розуміння сутності цих понять. 
Нині немає усталеної та остаточної сформованої думки про те, що ж таке «внутрішній контроль» і «система внутрішнього контролю». I наявність достатньої кількості визначень різних авторів - підтвердження цьому. У табл. 1 наведено, на нашу думку, найбільш поширені визначення поняття «внутрішній контроль», а в табл. 2 - «система внутрішнього контролю», що відображають квінтесенцію подібних дефініцій із досліджених 62 джерел.

Таблиия 1

Визначення поняття «внутрішній контроль»

\begin{tabular}{|c|c|}
\hline Джерело & Визначення \\
\hline 1 & 2 \\
\hline Білуха М. Т. [1] & $\begin{array}{l}\text { Уключає контрольні функції, які здійснюються } \\
\text { власниками підприємств, комбінатів, організацій } \\
\text { і підприємств, концернів, асоціацій відповідно до } \\
\text { чинного законодавства. }\end{array}$ \\
\hline Бутинець Т. А. [4] & $\begin{array}{l}\text { Є однією з основних функцій управління й систе- } \\
\text { мою постійного спостереження та перевірки роботи } \\
\text { фірми задля оцінки обгрунтованості й ефективно- } \\
\text { сті ухвалених управлінських рішень, виявлення } \\
\text { відхилень і несприятливих ситуацій, своєчасного } \\
\text { інформування керівництва для прийняття рішень } \\
3 \text { усунення, зниження ризиків його діяльності й } \\
\text { управлінню ними. }\end{array}$ \\
\hline $\begin{array}{l}\text { Кулаковська Л. П., } \\
\text { Піча Ю. В. [13] }\end{array}$ & $\begin{array}{l}\text { Внутрішній контроль як функція управління } є \\
\text { засобом зворотного зв’язку між об'єктом управління } \\
\text { й органом управління, інформуючи про дійсний } \\
\text { стан об'єкта та фактичне виконання управлінських } \\
\text { рішень. Внутрішній контроль - це процес, } \\
\text { який забезпечує відповідність функціонування } \\
\text { конкретного об'єкта прийнятим управлінським } \\
\text { рішенням і спрямований на успішне досягнення } \\
\text { поставленої мети. }\end{array}$ \\
\hline Бойко Р. [2] & $\begin{array}{l}\text { Являє собою систему, що містить усі елементи } \\
\text { організаційної структури - ресурси, процеси, } \\
\text { структура, професійна культура, які разом } \\
\text { об'єднають відповідних спеціалістів для досягнення }\end{array}$ \\
\hline
\end{tabular}


Закінчення таблиці 1

\begin{tabular}{|c|c|}
\hline 1 & 2 \\
\hline & $\begin{array}{l}\text { Цілей компанії й забезпечення достатнього рівня } \\
\text { ефективності та результативність підприємства, } \\
\text { правильності фінансових процесів і дотримання } \\
\text { законів та нормативних актів. }\end{array}$ \\
\hline $\begin{array}{l}\text { Мельник М. В., } \\
\text { Пантелєєв О. С., } \\
\text { Звездін А. Л. [8] }\end{array}$ & $\begin{array}{l}\text { Процес, спрямований на одержання достатньої } \\
\text { впевненості в тому, що економічний суб'єкт } \\
\text { забезпечує: } \\
\text { а) ефективність і результативність своєї діяльності, } \\
\text { у тому числі досягнення фінансових та операційних } \\
\text { показників, схоронність активів; } \\
\text { б) вірогідність і своєчасність бухгалтерської } \\
\text { (фінансової) й іншої звітності; } \\
\text { в) дотримання чинного законодавства, у тому числі } \\
\text { під час здійснення фактів господарського життя й } \\
\text { ведення бухгалтерського обліку. }\end{array}$ \\
\hline $\begin{array}{l}\text { Нагоєв А. Б., } \\
\text { Сижажева С. С., } \\
\text { Аппоева Ж. А. } \\
{[14]}\end{array}$ & $\begin{array}{l}\text { Це суцільний безперервний процес відстеження } \\
\text { якості управління цими організації, ефективності } \\
\text { роботи менеджменту, досягнення поставлених } \\
\text { цілей із мінімальними витратами, виявлення ризи- } \\
\text { ків та їх своєчасне запобігання, а також виявлення } \\
\text { внутрішніх резервів організації. }\end{array}$ \\
\hline
\end{tabular}

Таблиия 2

Визначення поняття «система внутрішнього контролю»

\begin{tabular}{|c|c|}
\hline Джерело & Визначення \\
\hline 1 & 2 \\
\hline $\begin{array}{l}\text { Постанова } \\
\text { Кабінету } \\
\text { Міністрів України } \\
\text { від 12.12.2018 p. } \\
\text { № } 1062[15]\end{array}$ & $\begin{array}{l}\text { Упроваджені керівником установи політики, } \\
\text { правила й заходи, які забезпечують функціонуванн, } \\
\text { взаємозв’язок та підтримку всіх елементів внутріш- } \\
\text { нього контролю й спрямовані на досягнення визна- } \\
\text { чених мети (місії), стратегічних та інших цілей, } \\
\text { завдань, планів і вимог щодо діяльності установи. }\end{array}$ \\
\hline Коба Е. Е. [6] & $\begin{array}{l}\text { Це функція управління, елемент системи управлін- } \\
\text { ня та організаційної структури управління, інфор- }\end{array}$ \\
\hline
\end{tabular}


Закінчення таблиці 1

\begin{tabular}{|l|l|}
\hline 1 & \multicolumn{1}{|c|}{$\mathbf{2}$} \\
\hline & $\begin{array}{l}\text { маційна база для прийняття управлінських рішень, } \\
\text { практична діяльність багатьох виконавців, які } \\
\epsilon \text { менеджерами всіх рівнів управління, а також } \\
\text { наукова категорія, що включає спостереження, } \\
\text { вивчення об'єкта контролю. }\end{array}$ \\
\hline Павлов М. І. [9] & $\begin{array}{l}\text { Це цілісна сукупність контрольного середовища } \\
\text { (співробітників, іх відносин, робочої атмосфери й } \\
\text { ін.), облікової системи та контрольних процедур, } \\
\text { що забезпечують досягнення й виконання завдань } \\
\text { внутрішнього контролю в організації. }\end{array}$ \\
\hline
\end{tabular}

Усю цю велику кількість визначень, на нашу думку, можна умовно й укрупнено розділити на такі групи:

- перша розглядає «внутрішній контроль» та «систему внутрішнього контролю», передусім, як функцію управління підприємством, що забезпечує, разом із функцією бухгалтерського обліку, інформаційну базу для прийняття управлінських рішень, а також зворотний зв'язок між об'єктом й суб'єктами управління;

- друга визначає «внутрішній контроль» та «систему внутрішнього контролю» як сукупність організаційних структур, політик, процедур, дій співробітників підприємства й іншого, наділених і виконуючих контрольні функції;

- третя вбачає «внутрішній контроль» та «систему внутрішнього контролю» як процесні дії 3 відповідними етапами, спрямовані на спостереження й контроль за фінансово-господарською або іншою діяльністю підприємства, і відповідність внутрішнім та зовнішнім нормативним документам, планам, іншим прийнятим управлінським рішенням, виявлення відхилень від прийнятих управлінських рішень, виявлення причин цих відхилень, коригування управлінських рішень у потрібному напрямі.

Вивчення та аналіз робіт зарубіжних фахівців у сфері управління й контролю $[3 ; 5 ; 7 ; 11 ; 16 ; 17 ; 18]$, а також матеріалів професійних організацій бухгалтерів й аудиторів із досліджуваних питань, дає підставу зробити висновок про те, що стан теорії внутрішнього контролю, теорії контролю й управління в цілому в СС та у світі аналогічний до стану в Україні. Суттєва відмінність полягає в більш сприятливій макроекономічній ситуації у світі і 
ЄC, порівняно з Україною. Подібна ситуація цілком з'ясована, ураховуючи вільний рух інформації у світовому масштабі.

На основі вищеозначеного, на нашу думку, внутрішній контроль - це економічна категорія; функція управління, що забезпечує спільно 3 функцією обліку, інформаційну базу для прийняття управлінських рішень, а також самостійно зворотний зв'язок між об'єктом і суб'єктом управління. Реалізація функції внутрішнього контролю відбувається в процесі управління через систему внутрішнього контролю, яка являє собою систему, котра містить усі елементи організаційної структури: ресурси всіх видів, процеси, структуру, організаційну інфраструктуру, професійну та загальну культуру, інтелектуальну складову, які разом об'єднають відповідних спеціалістів для досягнення цілей підприємства, його системи управління й забезпечення заданого рівня ефективності та результативності підприємства, правильності й ефективності фінансових процесів і дотримання законів, нормативних актів, стандартів, внутрішніх документів підприємства.

\section{3. ВИСНОВКИ ТА ПЕРСПЕКТИВИ ПОДАЛЬШИХ ДОСЛІДЖЕНЬ}

Проведені дослідження переконливо підтвердили виняткову важливість внутрішнього контролю, системи внутрішнього контролю в системі управління підприємствами, у тому числі таких, які працюють у сфері міжнародного бізнесу, їх значний, а в багатьох випадках вирішальний вплив на результати фінансово-господарської діяльності суб'єктів господарювання на сучасному етапі розвитку економіки України й світу.

Наявність багатьох думок, інколи діаметрально протилежних, на зміст, значення, роль, місце та інші найважливіші наріжні питання теорії внутрішнього контролю, системи внутрішнього контролю послаблюють теоретичну базу за цими напрямами й не сприяють ефективному вирішенню цих питань на практичному рівні. Це призводить до підвищення, нерідко непередбачуваного й критичного, різних ризиків під час ведення фінансовогосподарської діяльності суб'єктами господарювання як на вітчизняному ринку, так і у сфері міжнародного бізнесу, міжнародних відносин, що може вирішально позначатися на їхньому фінансово-господарському стані та стані економіки загалом.

Наукова новизна, теоретичне й практичне значення цієї роботи, на нашу думку, полягає в тому, що надано нові узагальнювальні, найбільш суттєві з чинних на сьогодні визначення термінів «внутрішній контроль» i «система внутрішнього контролю». Це має сприяти розробці теоретико- 
методологічних і концептуальних положень та організаційно-методичного забезпечення внутрішнього контролю, системи внутрішнього контролю в системі управління підприємством, більш точному й правильному визначенню всіх елементів внутрішнього контролю, системи внутрішнього контролю, їх взаємозв’язку та більш ефективному їх використанню в практичній діяльності. Це все може сприяти суттєвому зниженню ризиків фінансово-господарської діяльності та переведенню управління ними на якісно інший рівень.

Запропоновані визначення «внутрішнього контролю» й «системи внутрішнього контролю» повинні сприяти розвитку теорії за цими напрямами та стануть відправною точкою в подальших дослідженнях із питань теорії й практики внутрішнього контролю, а також теорії контролю та управління загалом, теорії менеджменту на всіх рівнях, у тому числі міжнародного.

\section{СПИСОК ВИКОРИСТАНИХ ДЖЕРЕЛ}

1. Білуха, М. Т. (1999). Курс аудиту. Київ: Вища шк., т-во «Знання», КОО.

2. Бойко, Р. (2016). Внутрішній контроль в інформаційній системі управління будівельною компанією. Інститут бухгалтерського обліку, контроль та аналіз в умовах глобалізаціï, 4, 102-108. URL: http://ibo.tneu.edu.ua/index.php/ibo/article/ view/303/303.

3. Borras, B. A. (2020). Internal Business Control Systems in Small Puerto Rican Retail Businesses. Walden Dissertations and Doctoral Studies. URL: https://scholarworks.waldenu.edu/dissertations/7994.

4. Бутинець, Т. А. (2008). Внутрішній контроль: суть і зміст. Вісник Житомирського державного технологічного університету, 2 (44), 31-42.

5. Iwejor, I. C. (2017). Internal Controls: Identifying Control Elements and implementation Dynamics Facing Retail Companies. Walden Dissertations and Doctoral Studies. URL: https://scholarworks.waldenu.edu/dissertations/4379.

6. Коба, Е. Е. (2012). Классификация форм и видов внутреннего контроля в агропромышленных холдингах. Региональная экономика: теория и практика, 3 (234), 42-49.

7. Lakis, V., \& Giriūnas, L. (2012). The concept of internal control system: theoretical aspect. Ekonomika, 91, 142-152. URL: https:/www.researchgate.net/publication/330519076.

8. Мельник, М. В., Пантелеев, А. С., \& Звездин, А. Л. (2011). Ревизия и контроль. Москва: Кнорус.

9. Павлов, М. И. (2018). Эффективное взаимодействие между службами внутреннего контроля и внутреннего аудита. Акционерное общество, 10(173), 148-156.

10. Соколов, Б. Н., \& Рукин, В. В. (2007). Системы внутреннего контроля (организация, методики, практика). Москва: ЗАО «Издательство “Экономика”».

11. Henk, O. (2020). Internal control through the lens of institutional work: a systematic literature review. Journal of Management Control, 31, 239-273. URL: https://doi. org/10.1007/s00187-020-00301-4. 
12. Семенець, А. О. (2019). Методологія внутрішнього аудиту в системі управління торговельними підприємствами. (Автореф. дис. ... д-ра. екон. наук) / Харківський державний університет харчування та торгівлі, Харків.

13. Кулаковська, Л. П., \& Піча, Ю. В. (2012). Організація і методика аудиту. Київ: Каравела.

14. Нагоев, А. Б., Сижажева, С. С., \& Аппоева, Ж. А. (2014). Роль внутреннего контроля в деятельности организаций. Фундаментальные исследования, 9, 2283-2287.

15. Основні засади здійснення внутрішнього контролю розпорядниками бюджетних коштів: Постанова Кабінету Міністрів України, № 1062. (2018). URL: https://zakon.rada.gov.ua/laws/show/1062-2018-\%D0\%BF\#Text].

16. Leng, J., \& Zhao, P. (2013). Study on the impact of the quality of internal control on the performance of M \& A. Journal of Service Science and Management, 6, 223-231. URL: doi:10.4236/jssm.2013.63025.

17. Mohd-Sanusi, Z., Johari, R. J., Said, J., \& Iskandar, T. (2015). The Effects of Internal Control System, Financial Management and Accountability of NPOs: The Perspective of Mosques in Malaysia. Procedia Economics and Finance, 28, 156-162.

18. Sulaiman, M., Siraj, S. A., \& Ibrahim, S. H. M. (2008). Internal Control Systems in West Malaysia's State Mosques. American Journal of Islam and Society, 25 (1), 63-81. URL: https://www.researchgate.net/publication/265537516.

\section{INTERNAL CONTROL AND INTERNAL CONTROL SYSTEM IN THE CONTEXT OF INTERNATIONAL BUSINESS: FORMALIZATION OF DEFINITIONS}

Nowadays the role and importance of internal control in financial, business and economic management is undeniably and significantly increasing. The research has revealed ambiguities among control theorists and practitioners on the underlying and attribute control issues, namely, the substance, content, role, meaning of internal control and the internal control system in the management of the enterprise, its financial and economic activities. This has a very negative impact on control practices, which in turn has a negative impact on the overall management of the enterprise and consequently on the final results of financial and economic activities. The purpose of this work is to study identified issues for systematization and consolidation, existing and possible approaches for defining the concepts of «internal control» and «internal control system». Research has shown that the formalization of the definitions of «internal control», «internal control system» is of great importance for the development of conceptual and categorical apparatus, both in the theory of control and management, and in economic science in general, it is also fundamental to the practice of management, control and conduct of financial and economic activities in modern business conditions. The existing approaches of domestic and foreign specialists in the sphere of control and management, both theoretical and practical, to the defini- 
tion of notions «internal control», «system of internal control» are summarized and grouped. The studies carried out convincingly show that the introduction of internal control systems in a significant part of domestic enterprises, especially large and medium-sized enterprises in a crisis and pre-crisis state, is currently one of the primary tasks that helps to overcome crisis phenomena, significantly reduce risks, and as a result, improving the efficiency of all financial and economic activities. As a result of the research carried out, the author defined the concepts «internal control» and «internal control system», which in our opinion should contribute to further development of theory and practice of control activity, management, international management.

Key words: internal control; internal control system; management; control; audit; international management; international business.

\section{REFERENCES}

1. Bilukha, M. T. (1999). Audit course. Kyiv: Vyshcha shkola. T-vo «Znannia», KOO (in Ukrainian).

2. Boiko, R. (2016). Internal control in the information system of management of the construction company. Instytut bukhhalterskoho obliku, kontrol ta analiz $v$ umovakh hlobalizatsii, 4, 102-108. URL: http://ibo.tneu.edu.ua/index.php/ibo/article/view/303/303 (in Ukrainian).

3. Borras, B. A. (2020). Internal Business Control Systems in Small Puerto Rican Retail Businesses. Walden Dissertations and Doctoral Studies. URL: https://scholarworks.waldenu.edu/dissertations/7994.

4. Butynets, T. A. (2008). Internal control: essence and content. Visnyk Zhytomyrskoho derzhavnoho tekhnolohichnoho universytetu, 2 (44), 31-42 (in Ukrainian).

5. Iwejor, I. C. (2017). Internal Controls: Identifying Control Elements and implementation Dynamics Facing Retail Companies. Walden Dissertations and Doctoral Studies. URL: https://scholarworks.waldenu.edu/dissertations/4379.

6. Koba, E. E. (2012). Classification of forms and types of internal control in agro-industrial holdings. Regional'naja jekonomika: teorija i praktika, 3 (234), $42-49$ (in Russian).

7. Lakis, V., \& Giriūnas, L. (2012). The concept of internal control system: theoretical aspect. Ekonomika, 91, 142-152. URL: https://www.researchgate.net/publication/330519076.

8. Mel'nik, M. V., Panteleev, A. S., \& Zvezdin, A. L. (2011). Revision and control. Moscow: Knorus (in Russian).

9. Pavlov, M. I. (2018). Effective interaction between internal control and internal audit services. Akcionernoe obshhestvo, 10(173), 148-156 (in Russian).

10. Sokolov, B. N., \& Rukin, V. V. (2007). Internal control systems (organization, methods, practice). Moscow: ZAO «Izdatel'stvo «Jekonomika» (in Russian).

11. Henk, O. (2020). Internal control through the lens of institutional work: a systematic literature review. Journal of Management Control, 31, 239-273. URL: https://doi. org/10.1007/s00187-020-00301-4.

12. Semenets, A. O. (2019). Methodology of internal audit in the retail enterprise management system. (Extended abstract of Doctor dissertation). State University of Food Technology and Trade, Kharkiv (in Ukrainian). 
13. Kulakovska, L. P., \& Picha, Yu. V. (2012). Organization and methods of audit. Kyiv: Karavela.

14. Nagoev, A. B., Sizhazheva, S. S., \& Appoeva, Zh. A. (2014). The role of internal control in the activities of organizations. Fundamental'nye issledovanija, 9, 2283-2287 (in Russian).

15. The main principles of internal control by managers of budget funds: Resolution of the Cabinet of Ministers of Ukraine, № 1062, (2018). URL: https://zakon.rada. gov.ua/laws/show/1062-2018-\%D0\%BF\#Text] (in Ukrainian).

16. Leng, J., \& Zhao, P. (2013). Study on the impact of the quality of internal control on the performance of M \& A. Journal of Service Science and Management, 6, 223-231. URL: doi:10.4236/jssm.2013.63025.

17. Mohd-Sanusi, Z., Johari, R. J., Said, J., \& Iskandar, T. (2015). The Effects of Internal Control System, Financial Management and Accountability of NPOs: The Perspective of Mosques in Malaysia. Procedia Economics and Finance, 28, 156-162.

18. Sulaiman, M., Siraj, S. A., \& Ibrahim, S. H. M. (2008). Internal Control Systems in West Malaysia's State Mosques. American Journal of Islam and Society, 25 (1), 63-81. URL: https://www.researchgate.net/publication/265537516.

Матеріал надійшов до редакиії 02.01. 2021 р. 